\title{
'AC-L'Acadie' Strawberry
}

\author{
Shahrokh Khanizadeh ${ }^{1}$, Bertrand Thériault ${ }^{2}$, and Odile Carisse ${ }^{3}$ \\ Agriculture and Agri-Food Canada, Research Station, 430 Blvd. Gouin, St- \\ Jean-sur-Richelieu, QC, Canada, J3B 3E6

\section{Deborah Buszard ${ }^{4}$ Canada, H9X $1 C 0$} \\ Department of Plant Science, McGill University, Ste-Anne-de-Bellevue, Quebec,
}

Additional index words. Fragaria $\times$ ananassa, fruit breeding, storage, shelf-life, red stele

\begin{abstract}
'AC-L'Acadie' is a new June-bearing strawberry cultivar (Fragaria Xananassa Duch.) bred for Quebec and Eastern Central Canada growing conditions. 'AC-L'Acadie' produces large, firm fruit and the plants are moderately resistant to leaf diseases and partially resistant to the principal eastern races of red stele (Phytophthora fragariae Hickman). 'AC-L'Acadie' fruit store very well at room temperature for several days, making them ideal for shipping or for growers who need to store fresh fruit. The cultivar is recommended for pick-your-own and/or fresh-market producers.
\end{abstract}

The Prefix "AC" in the name stands for "Agriculture and Agri-Food Canada." The name 'L'Acadie' was chosen because this cultivar was originally selected at the L'Acadie substation of Agriculture and Agri-Food Canada and it was tested there for several years. This is also the site where much of the strawberry research and breeding is being conducted in the province of Quebec.

\section{Origin}

'AC-L'Acadie', tested as SJ8916-50, is a seedling resulting from a cross between 'Glooscap' and 'Guardian' made in 1989 by S. Khanizadeh. 'Glooscap' was used as a parent because of its high yields of high-quality, glossy, dark-red fruit with a reflexed calyx (Craig et al., 1991). 'Guardian' was used as a parent because of its large, firm, pale red fruit and its known resistance to five races of red stele, powdery mildew (Sphaerotheca macularis Walls ex Fr.), leaf scorch (Diplocarpon earlina Ell. and Ev.), and verticillium wilt (Verticillium albo-atrum Reinke \& Berth.) (Brooks and Olmo, 1997).

Received for publication 2 Nov. 1998. Accepted for publication 1 Mar. 1999. Agriculture and Agri-Food Canada, St-Jean-sur-Richelieu, Contribution No. 335/99.04.01R. The cost of publishing this paper was defrayed in part by the payment of page charges. Under postal regulations, this paper therefore must be hereby marked advertisement solely to indicate this fact.

${ }^{1}$ Research Scientist and Adjunct Professor, Breeder, Physiologist, and Statistician.

${ }^{2}$ Technician.

${ }^{3}$ Research Scientist, Pathologist.

${ }^{4}$ Associate Professor and Dean, Fruit Specialist.
'AC-L'Acadie' has been tested at the Agriculture and Agri-Food Canada substation in L'Acadie, Quebec, since 1990, and at the Macdonald Campus of McGill Univ. in SteAnne-de-Bellevue during the 1992-94 fruiting seasons. It was also evaluated from 199698 in controlled semi-commercial sites by our private partners Lareault Inc., Les Fraises de l'Ile d'Orleans Inc. in Quebec and Réseau d'Essais Petits Fruits-CPVQ Inc. (Quebec Regional small fruit trials, Conseil des productions végétales du Québec).

\section{Description and performance}

Plants of 'AC-L'Acadie' are vigorous and have four to seven inflorescences per crown. They can tolerate winter temperatures below $-30{ }^{\circ} \mathrm{C}$ (with 10 -cm straw mulch cover). Peti- oles are $12-22 \mathrm{~cm}$ long, and the leaflets are longer than broad (1.25:1), large, dark green, flat, shiny, and obovate, each with $\approx 17-24$ serrations.

'AC-L'Acadie' produces large, shiny, pale red fruit that ripen in midseason (Fig. 1, Tables 1 and 2). Fruit shape is necked-conic and the semi-reflexed calyces decap as easily as those of 'Chambly' and 'Glooscap'. The flesh is lighter red than the skin and is sweet and firm (Table 2). Fresh fruit store very well for up to $5 \mathrm{~d}$ at room temperature and frozen fruit retain their integrity after thawing.

'AC-L'Acadie' produced yields similar to those of 'Joliette', 'Oka', 'Kent', 'Glooscap', and 'Chambly' during 1995-98 (Table 1). The index of crop concentration of 'AC-L'Acadie' was very similar to that of 'Joliette', but more concentrated than that of 'Kent'. No symptoms of powdery mildew were observed on 'AC-L'Acadie' in any of the sites during all the years of testing. 'AC-L'Acadie' had the same level of tolerance to leaf scorch, leaf blight (Dendrophoma obscurans Ell. and Ev.), and leaf spot [Mycosphaerella fragariae (Tul.) Lindau] as did 'Honeoye'. No signs of gray mold fruit rot (Botrytis cinerea Pers. ex Fr.) were observed for any cultivars except 'Glooscap', which showed intermediate susceptibility. 'AC-L'Acadie' plants were ranked partially resistant to the six North American Eastern (NAE) races of red stele (A1 to A6) in a controlled environment (Khanizadeh et al., 1997). The plants are tolerant to the herbicide terbacil [5-chloro-3-(1,1-dimethylethyl)-6methyl-2,4-(1H,3H)-pyrimidine-dione].

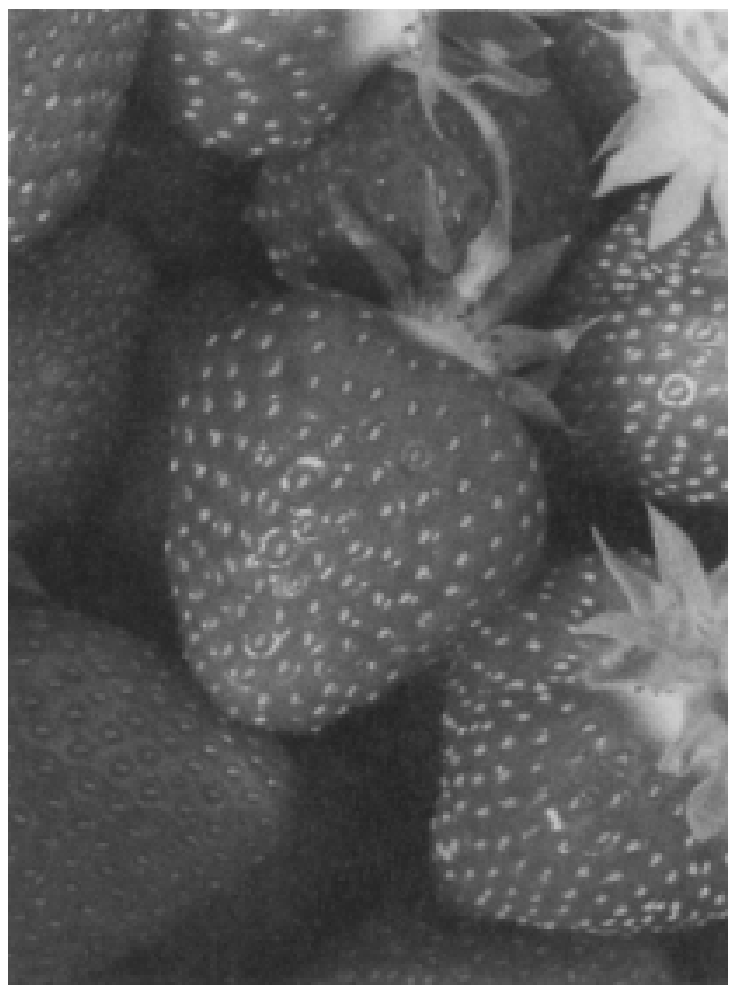

Fig. 1. Fruit of 'AC-L'Acadie' strawberry. 
Table 1. Yield distribution ( $\mathrm{g} \cdot \mathrm{m}^{-1}$ of row), indices of crop concentration and earliness, ripening season, and total yield of 'AC-L'Acadie' compared with those of other genotypes.

\begin{tabular}{|c|c|c|c|c|c|c|c|c|c|c|c|c|}
\hline \multirow[b]{3}{*}{ Genotype } & \multicolumn{7}{|c|}{ Harvest $^{\mathrm{z}}$} & \multirow{3}{*}{$\begin{array}{c}\text { Total yield } \\
\left(\mathrm{g} \cdot \mathrm{m}^{-1}\right)^{\mathrm{y}}\end{array}$} & \multirow{3}{*}{$\begin{array}{c}\text { Wt/fruit } \\
(\mathrm{g})^{\mathrm{y}}\end{array}$} & \multirow{3}{*}{$\begin{array}{c}\text { Ripening } \\
\text { season }^{\mathrm{x}}\end{array}$} & \multirow{3}{*}{$\begin{array}{c}\text { Index of crop } \\
\text { concn }^{w}\end{array}$} & \multirow{3}{*}{$\begin{array}{l}\text { Index of } \\
\text { earliness }\end{array}$} \\
\hline & 1 & 2 & 3 & 4 & 5 & 6 & 7 & & & & & \\
\hline & $(1)$ & $(6)$ & (9) & $(13)$ & (16) & $(22)$ & $(28)$ & & & & & \\
\hline AC-L'Acadie & 108 & 102 & 427 & 1004 & 501 & 504 & 197 & 2841 & 14.5 & $\mathrm{M}$ & 1.5 & 2.1 \\
\hline Joliette & 209 & 542 & 711 & 749 & 338 & 205 & --- & 2752 & 15.3 & M & 1.4 & 2.5 \\
\hline Oka & 516 & 467 & 607 & 520 & 291 & 254 & --- & 2653 & 13.6 & M & 1.0 & 3.0 \\
\hline Kent & 409 & 443 & 443 & 385 & 255 & 263 & 154 & 2350 & 14.0 & M & 0.6 & 2.5 \\
\hline Glooscap & 385 & 563 & 651 & 342 & 221 & 161 & --- & 2322 & 11.8 & M & 1.3 & 2.5 \\
\hline Chambly & 591 & 466 & 486 & 325 & 262 & 157 & --- & 2286 & 13.9 & EM & 1.2 & 2.9 \\
\hline Honeoye & 695 & 344 & 297 & 218 & 296 & 156 & 222 & 2226 & 11.8 & $\mathrm{E}$ & 1.1 & 3.0 \\
\hline Jewel & 135 & 378 & 451 & 393 & 234 & 248 & --- & 1837 & 13.9 & M & 1.1 & 1.6 \\
\hline $\mathrm{LSD}_{0.05}$ & & & & & & & & 600 & 2.3 & & 0.6 & 1.1 \\
\hline
\end{tabular}

${ }^{\mathrm{z}}$ Number of times fruit were harvested during the season; the number in brackets is the cumulative day after the first harvest during $1995-98$.

${ }^{y}$ Averaged over 4 years (1995-98), minimum of four replications per year, data from the L'Acadie site, genotypes are ranked by total yield.

${ }^{x} \mathrm{~L}=$ late, $\mathrm{M}=$ midseason, $\mathrm{EM}=$ early-midseason, $\mathrm{E}=$ early.

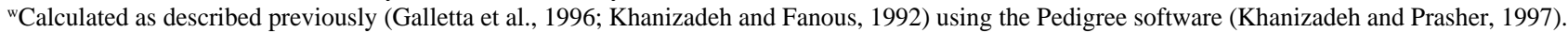

Table 2. Firmness, flavor, skin color, and shelf life of 'AC-L'Acadie' compared with those of other genotypes. $^{z}$

\begin{tabular}{lcccc}
\hline Genotypes & Firmness $^{\mathrm{y}}$ & Flavor $^{\mathrm{y}}$ & Skin color $^{\mathrm{y}}$ & Shelf life $^{\mathrm{x}}$ \\
\hline AC-L'Acadie & 4.1 & 3.3 & 2.0 & 5 \\
Joliette & 4.2 & 3.3 & 2.8 & 4 \\
Oka & 2.0 & 3.7 & 4.0 & 1 \\
Kent & 3.0 & 3.0 & 2.2 & 2 \\
Glooscap & 2.7 & 3.1 & 3.6 & 1 \\
Chambly & 4.0 & 3.7 & 3.8 & 3 \\
Honeoye & 3.0 & 3.0 & 3.0 & 1 \\
Jewel & 4.0 & 3.0 & 2.6 & 3 \\
LSD $_{0.05}$ & 0.1 & 0.2 & 0.2 & 1.3 \\
\hline
\end{tabular}

${ }^{2}$ Averaged over 4 years (1995-98), minimum of four replications per year, data from the L'Acadie site. ${ }^{y}$ Data were transformed to arcsin prior to analysis of variance (SAS Institute, 1988). Firmness: $1=$ very soft, $5=$ very firm; flavor: $1=$ poor, $5=$ excellent; skin color: $1=$ very pale, $5=$ dark red. See Khanizadeh et al. (1994) for details on score evaluation.

${ }^{\mathrm{x}}$ Number of days at room temperature for which the fruit were $>95 \%$ marketable.

\section{Area of adaptation and uses}

'AC-L'Acadie' is recommended for Eastern Central Canada, especially in areas where the climate is similar to that in Quebec. It is ideal for shipping because of its good postharvest fruit quality and integrity. It performs very well in sandy soils and in compact or heavy soils similar to those in L'Acadie where this genotype was first selected. 'AC-L'Acadie' is presently being evaluated in other provinces of Canada, in the United States, and in Europe.

\section{Availability}

A patent is pending for 'AC-L'Acadie'. Plants can be purchased from licensed nurseries in Quebec and licenses for multiplication can be obtained from Agriculture and AgriFood Canada. European nurseries can obtain a multiplication license from Meiosis Ltd. (Bradbourne House, Stable Block, East Malling, Kent ME196DZ). A limited number of plants are available from the author (SK) for research purposes.

\section{Literature Cited}

Brooks, R.M. and H.P. Olmo. 1997. Register of fruit $\&$ nut varieties. 3 rd ed. ASHS Press, Alexandria, Va.

Craig, D.L., A.R. Jamieson, and K.A. Sanford. 1991. Glooscap and Blomidon strawberries. Can. J. Plant Sci. 71:937-941.

Galletta, G.J., J.L. Maas, J.M. Enns, J.C. Scheerens, R. Rouse, and R.F. Heflebower, Jr. 1996. 'Primetime' strawberry. HortScience 31:10381042.

Khanizadeh, S. and M.A. Fanous. 1992. Mathematical indices for comparing small fruit crops and trait similarity. HortScience 27:346-348.

Khanizadeh, S., J. Fortin, M.J. Lareau, and D. Buszard. 1994. Sensory evaluation of six strawberry cultivars after machine harvest, p. 249254. In: H. Schmidt and M. Kellerhals (eds.). Prog. in temperate fruit breeding. Kluwer Academic, The Netherlands.

Khanizadeh, S., A. Gruber, O. Carisse, D. Buszard, and P.O. Thibodeau. 1997. Red-stele susceptibility of advanced strawberry selections from Quebec. Acta Hort. 439:189-193.

Khanizadeh, S. and S.O. Prasher. 1997. Pedigree ${ }^{\circledR}$ : A database program to draw pedigrees, trace traits, and view images of strawberry genotypes. Adv. in Strawberry Res. 16:67.

SAS Institute. 1988. Statistical analysis system. SAS/STAT, SAS/BASIC guide for personal computers, version 6.04 ed. SAS Inst., Cary, N.C. 